\title{
FLOWERING, POLLEN CHARACTERISTICS AND INSECT FORAGING ON Campanula bononiensis (CAMPANULACEAE), A PROTECTED SPECIES IN POLAND
}

\author{
${ }^{1}$ Bożena Denisow, ${ }^{2}$ Małgorzata Wrzesień, ${ }^{1}$ Małgorzata Bożek, \\ ${ }^{1}$ Anna Jeżak ${ }^{1}$ Monika Strzałkowska-Abramek

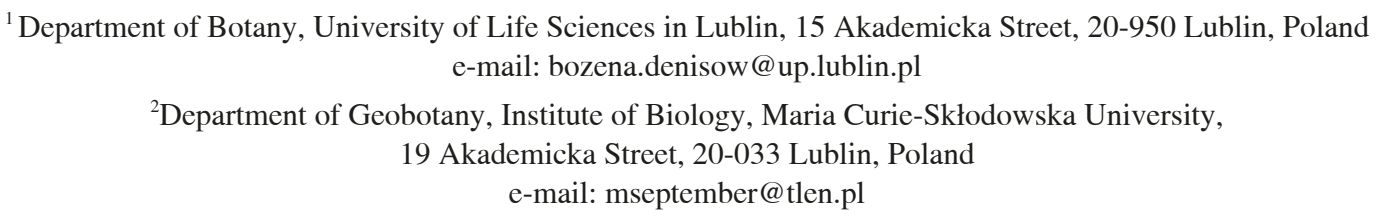

Received: 27.01.2014

\begin{abstract}
This study investigated the floral biology and pollen quantity and quality of Campanula bononiensis L. (Campanulaceae), a protected species in Poland. Observations and measurements were made during the years 2007-2009 in natural phytocoenoses from the Festuco-Brometea class situated within the Lublin area, SE Poland. A considerable decrease (approx. $87 \%$ ) in population density was observed. Significant variations both in the amount of pollen $(18.5 \%-34.8 \%$ of pollen in the total anther dry weight, i.e. $0.5-1.5 \mathrm{mg}$ per 10 anthers) and in pollen viability (38.8-97.0\%) were noted. Both a low amount of pollen and low pollen viability may reduce the reproductive success of individuals. The most frequent visiting insects were bees (Apoidea), including solitary bees $45.7 \%$, honeybees $20.4 \%$, and bumblebees $11.4 \%$. Dipterans, coleopterans (weevils), lepidopterans and ants were also recorded, implying a strong impact of $C$. bononiensis on insect biodiversity within grasslands.
\end{abstract}

Key words: Campanula bononiensis, grasslands, population size, pollen quantity, pollen viability, insect visitors

\section{INTRODUCTION}

The interaction of plants with pollinating agents is vital for the structural and functional integrity of natural ecosystems. The concept includes several aspects, i.e. the stability of pollination webs $[1,2]$. Their maintenance is one of the most important challenges and can be obtainable by conservation of plant species biodiversity. It is believed that the understanding of the floral biology of wild species threatened with extinction may contribute to their protection and through this our understanding of different interactions linking organisms within biocenosis may be improved [3]. In entomophilous plants, besides the nectar, pollen serves as an attractant [4]. Pollen of entomophilous species has a double function in a biocenosis. Firstly, it serves as a donor of male gametes and therefore has evolved to increase the efficiency of reproduction by qualitative and quantitative traits [5-8]. Secondly, it serves as a rich source of high-quality protein pollen, which is an important food for a variety of insect visitors that need a continuous food supply throughout the whole life cycle $[9,10]$.

The genus Campanula includes over 500 species of herbaceous plants, distributed across the temperate regions of the Northern Hemisphere, with the highest diversity in the Mediterranean region east to the Caucasus [11]. Among the genus Campanula, 9 species are recorded in natural phytocoenoses in Poland [12, 13]. Species from the genus Camapanula are particularly important for oligolectic bees, i.e. specialized and with a narrow preference to collect pollen exclusively from Campanula flowers $[14,15]$. To date, most studies on Campanula spp. focused on descriptions of style trichomes (PCHs-pollen collecting hairs), dichogamy and secondary pollen presentation mechanisms [9, 16-19]. The adaptive significance of the hairs in relation to pollination has been interpreted in relation to the plant reproductive success $[20,21]$. 
The aim of the presented study was (1) to identify the phenology of blooming; (2) to determine the population density and blooming abundance; (3) to show the qualitative and quantitative pollen traits; and (4) to record the spectrum of insect pollinators on Cатрапиla bononiensis, a protected species in Poland.

\section{MATERIALS AND METHODS}

Study site and species description. The observations and measurements were carried out during the years 2007-2009 in natural phytocoenoses from the Festuco-Brometea class situated within the Lublin area (FE2766, 51 ${ }^{\circ} 16^{\prime} \mathrm{N}, 22^{\circ} 30^{\prime}$ E, $200 \mathrm{~m}$ a.s.l.), the Lublin Upland, SE Poland.

Campanula bononiensis L. (Campanulaceae) is a species with high microhabitat demands and prefers edges of thermophilous woods and thickets as well as closed xerothermic tall-grass meadows. Detailed autoecological characteristics are shown in Figure 1. The species is considered to be characteristic of two alliances: Cirsio-Brachypodion pinnati grasslands of Festuco-Brometea and Geranion sanguinei-fringe communities of thermophilous herbs of Trifolio-Geranietea class [22]. The species is rare in Central Europe and is protected by law in Poland [23, 24].

Flowering and insect visitors' activity. Protocols described by Jabłoński and Szklanowska [25] as well as by Denisow [7] were applied. During the growing seasons, the onset and length of flowering were established. Due to time-consuming observations, the diurnal flowering pattern was established only in 2007 and 2008. The observations were conducted from 8.00 till $19.00(\mathrm{GMT}+2.00 \mathrm{~h})$ and in two-hour intervals newly opened flowers were counted $(\mathrm{n}=6$ individuals); night anthesis was excluded. Simultaneously to the blooming observations, insect visits were recorded $\left(\mathrm{n}=4\right.$ random plots of $\left.1 \mathrm{~m}^{2}\right)$. These observations were made for three consecutive days, at the full bloom stage of the population. During each observation, the total number of visiting insects was recorded. The abundance of blooming was determined by the number of flowers produced during the life cycle, i.e. all buds, flowers and fruits per stem were counted. The population density was established on the basis of 10-30 random circular $0.1 \mathrm{~m}^{2}$ areas $(36.7 \mathrm{~cm}$ in diameter). The data was converted to the number of flowers per $10 \mathrm{~m}^{2}$.

Quantity and quality of pollen. In order to measure the amount of pollen production, the ether method was used [8]. During each season, well-developed flower buds were randomly chosen at the full flowering stage, before the anthers dehisced. The anthers were dissected and placed in tarred vessels. Four samples were collected ( $\mathrm{n}=50$ stamens). Stamen heads were assayed for fresh and dry weight and for the weight of pollen contained in them. Samples were placed in a dryer (ELCON CL 65) at ca. $33^{\circ} \mathrm{C}$. The pollen was rinsed once with pure ether $(2 \mathrm{ml})$ and then 2-3 times with $70 \%$ ethanol (3-4 ml). Pollen viability $(\mathrm{n}=3 \times 100)$ was examined in standard acetocarmine-stained slides, while the size of pollen grains in glycerogelatin slides $(n=4 \times 50)$. Pollen features were observed by light microscopy (Nikon Eclipse E-200).

The weather pattern. Weather data were obtained from a weather station located in Lublin (Felin). Monthly and 10-day means were compared to the long-term data (1951-2005). The general weather pattern differed between growing seasons. In 2007 the temperatures were above normal (May by $+2^{\circ} \mathrm{C}$, June by $+1.9^{\circ} \mathrm{C}$, July $+1.4^{\circ} \mathrm{C}$ ) and rainfall was higher than normal (May by $23.8 \mathrm{~mm}$, June by $22.1 \mathrm{~mm}$, July by $3.5 \mathrm{~mm}$ ). The beginning of 2008 was colder compared to the long-term data. Spring was early with March and April temperatures higher than the long-term average (by $+2.3^{\circ} \mathrm{C}$ and $+1.9^{\circ} \mathrm{C}$, respectively). May was very wet with rainfall approx. 50\% higher than the long-term average. Summer was dry with rainfall in June $65 \%$ lower compared to the long-term average. The air temperatures in the spring of 2009 were at an average level, but the rainfall was twice higher than normal. In June the rainfall was approx. $130 \%$ higher than normal, whereas July was very dry (rainfall lower by $75 \%$ ).

Data analysis. Analysis of variance (ANOVA) was applied [26]. The data are presented as means with SD. Parametric statistical analysis was applied for the pollen traits. Post hoc comparison of means was tested by Tukey's HSD test. The Kruskal-Wallis test for unequal size groups was used to determine the differences for non-normally distributed data (population density, number of flowers per individual). Paerson's correlation $(r)$ of the mass of produced pollen against the dry weight of anthers was determined. The level of statistical significance for all analyses was at $P=0.05$. All analyses were performed using Statistica ver. 6.0 (StatSoft Poland, Krakow).

\section{RESULTS}

Under the climate conditions of SE Poland, during 2007-2009 the flowering of Campanula bononiensis began in late June and lasted till the middle of September (Fig. 2). The phenology of flowering differed between the years of study. A two-week shift for the onset of flowering was noted between 2007 and 2009. The duration of seasonal flowering varied from 6 to 10 weeks. The flowers of $C$. bononiensis are perfect, actinomorphic and are day-opening. Most flowers opened between $9.00 \mathrm{~h}$ and $12.00 \mathrm{~h}$, and the process continued till 17.00, GMT+2h (Fig. 3). The flowers are distinctly protandrous and therefore both functionally male-phase 
and female-phase flowers were present on individuals (Fig. 4B, C). At the bud stage, the anthers were rigid and formed a narrow tube (Fig. 4D). The style with closed lobes was centrally positioned and the anthers touched closely to the style. Most anthers dehisced in well-developed buds and before corolla opening the male phase started. The release of pollen began in the apical part of the anthers and sticky pollen covered trichomes present on the style (Fig. 4E). The presentation of pollen to insects lasted for 1-2 days per flower. The centrally located style exhibited a 3-curled stigma during the female phase.

A year effect was found for the number of flowers produced per plant $(P=0.0328)$ and for the population density $(P=0.0287)$ (Table 1$)$. The number of flowers formed per individual was $66.9 \pm 44.6 \mathrm{SD}$, ranging from 24 to 112. In 2009 the individuals produced 2 times fewer flowers, compared with the other years. The number of individuals decreased by $97 \%$ between 2007 and 2009. The total number of flowers per unit area also differed significantly between growing seasons $(P=0.0314)$.

A year effect was found for the size of anthers, measured as the (fresh and dry) mass of anthers $\left(\mathrm{F}_{2,21}=23.29, P=0.021, \mathrm{~F}_{2,21}=8.34, P=0.035\right.$, respectively). The smallest anthers were recorded in 2009, while almost twice larger anthers were observed in 2008 (Table 2). The mean value of the fresh weight for 10 anthers, including pollen, ranged between years from 4.3 to $7.9 \mathrm{mg}$ (mean $=6.2$ ). The mean dry weight of anthers was accordingly lower and ranged from
2.7 to $4.3 \mathrm{mg}$ (mean $=3.3)$. The percentage participation of pollen in anthers varied and depended on the study year. In the anthers of $C$. bononiensis, pollen accounted for $18.5-34.8 \%$ of the total anther dry weight (Table 2). The mass of pollen per 10 anthers correlated positively with anther dry mass (Pearson's correlation $r=0.8622$ ). A significantly higher amount of pollen per 10 anthers was produced in 2008. The differences between means for years were significant $\left(\mathrm{F}_{2,21}=5.32\right.$, $P=0.014)$. Pollen viability varied between the years of study. The lowest number of pollen grains with a viable protoplast was found in 2009 (mean $=38.8 \%$ ), while the highest one in 2008 (mean $=97.0 \%$ ). The pollen grain of Campanula bononiensis is trizonoporate circular in polar view and oblate-spheroidal in equatorial view (Fig. 4F, G). The mean value of the $\mathrm{P} / \mathrm{E}$ ratio is 0.91. The polar axis $(\mathrm{P})$ ranged 27.66-30.94 $\mu \mathrm{m}$, mean $29.05 \mu \mathrm{m}$; the equatorial axis (E) ranged 29.61-34.35, mean $=31.82 \mu \mathrm{m}$.

The percentage participation of insect visitors is presented in Figure 5. The primary visitors were Apoidea bees. The participation of Apis mellifera and solitary bees substantially varied between years. Solitary bees predominated on the flowers and contributed $45.7 \%$ of visits, on average (ranging $33.0-58.4 \%$ ). Apis mellifera accounted for an average of $20.4 \%$ of visits (ranging 12.3-28.5\%). The inter-annual percentage of bumblebees (8.8-13.9\%) and dipterans was almost steady (10-13\%). Coleoptera and Formicidae accounted for $\sim 5 \%$ of visits each. Butterflies were sporadically found on the flowers, only in 2007.

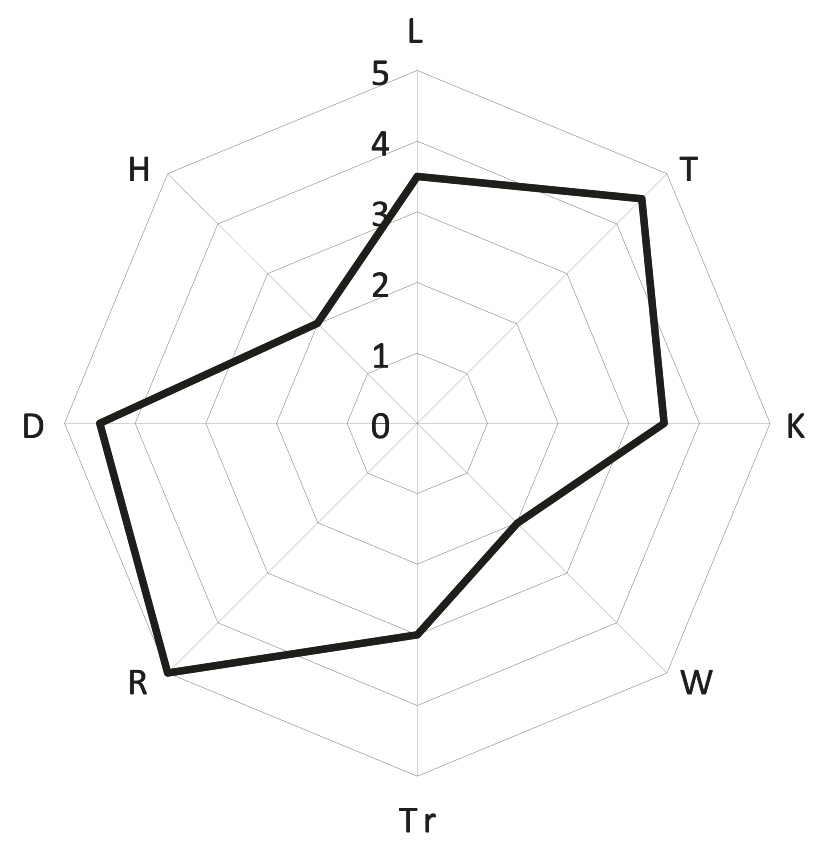

Fig. 1. The synthetic autecological characteristics of Camanula bononiensis based on Ellenberg ecological numbers; $\mathrm{L}-$ light, $\mathrm{T}-$ temperature, $\mathrm{K}$ - continentality, $\mathrm{W}$ - soil moisture, $\mathrm{Tr}$ - soil trophy, $\mathrm{R}$ - soil reaction, D - soil granulometry, $\mathrm{H}$ - soil humic matter content 
$\diamond$ full blooming phase

2007

2008

2009

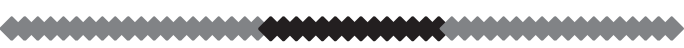

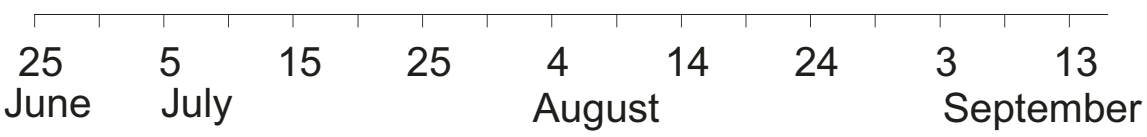

Fig. 2. Phenology of flowering of Campanula bononiensis in the years 2007-2009 observed in SE Poland.

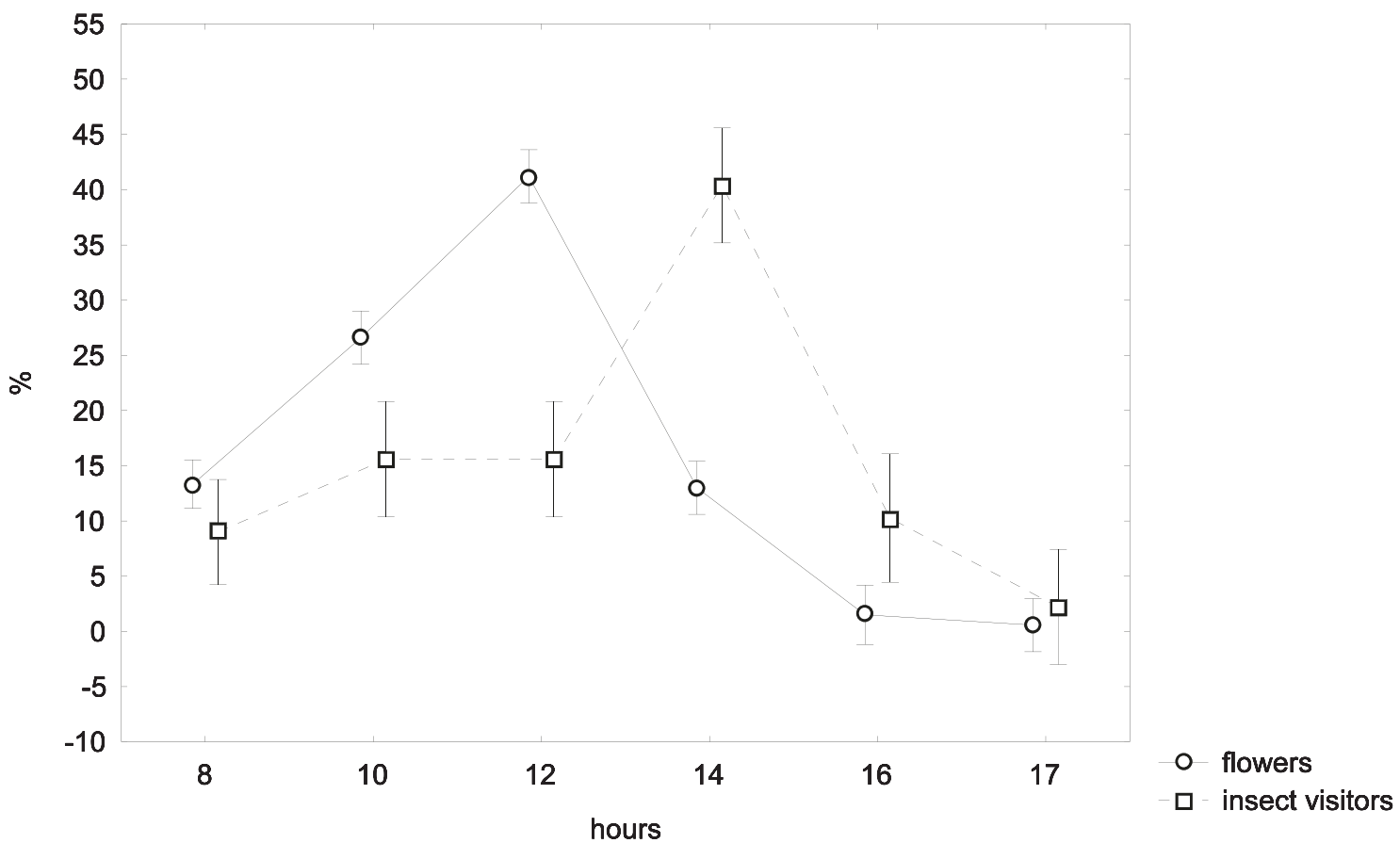

Fig. 3. Diurnal pattern of flowering of Campanula bononiensis expressed as the number of flowers opened in two-hour intervals in relation of the total opened during the day and the diurnal activity of insect visitors (mean for all species noted) observed in SE Poland (means calculated from 2007 and 2008). Vertical bars indicate 95\% confidence intervals.

Table 1

The number of flowers per individual, the population density and the total abundance of blooming of Campanula bononiensis in the years 2007-2009.

Year effect was tested according to Kruscal-Wallis test

\begin{tabular}{|c|c|c|c|c|c|c|c|}
\hline \multirow{3}{*}{ Variable } & \multicolumn{6}{|c|}{ Year } & \multirow{3}{*}{$P$-value } \\
\hline & \multicolumn{2}{|c|}{2007} & \multicolumn{2}{|c|}{2008} & \multicolumn{2}{|c|}{2009} & \\
\hline & Mean & $\pm \mathrm{SD}$ & Mean & $\pm \mathrm{SD}$ & Mean & $\pm \mathrm{SD}$ & \\
\hline flowers per individual & 71.2 & 21.4 & 86.1 & 32.2 & 43.6 & 21.8 & 0.0328 \\
\hline individuals per $10 \mathrm{~m}^{2}$ & 47.8 & 32.2 & 22.6 & 6.6 & 4.3 & 1.6 & 0.0287 \\
\hline flowers per $10 \mathrm{~m}^{2}$ (thousands) & 3.4 & 1.2 & 1.9 & 1.4 & 0.2 & 0.1 & 0.0314 \\
\hline
\end{tabular}



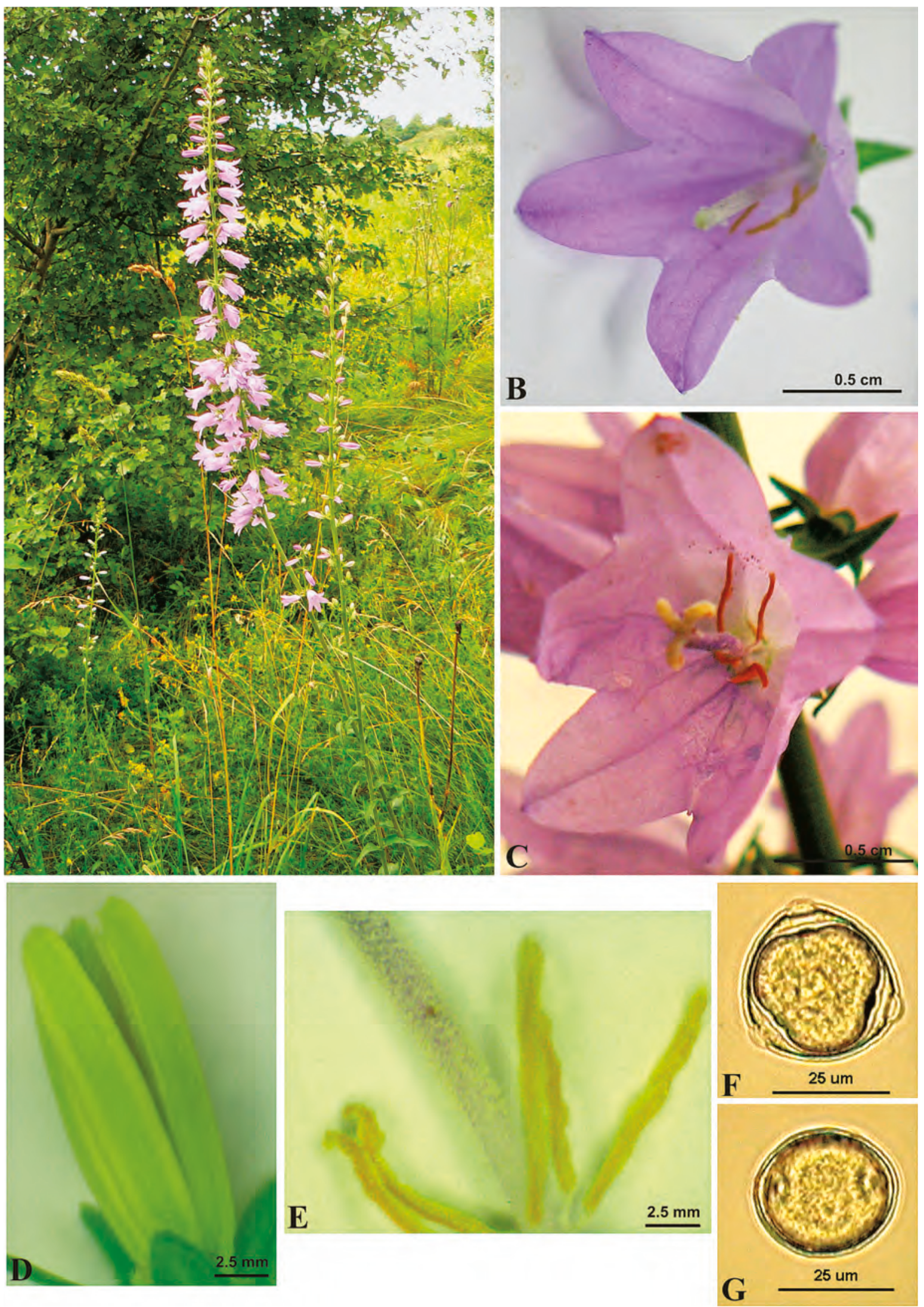

Fig. 4. Campanula bononiensis $\mathrm{A}$ - at full bloom in the phytocoenoses from Festuca-Brometea class; B - male-phase flower; $\mathrm{C}$ - female-phase flower; $\mathrm{D}$ - anthers in the bud stage; $\mathrm{E}$ - pollen presentation on the style; $\mathrm{F}$ - pollen grain - polar view; $\mathrm{G}$ - pollen grain - equatorial view 


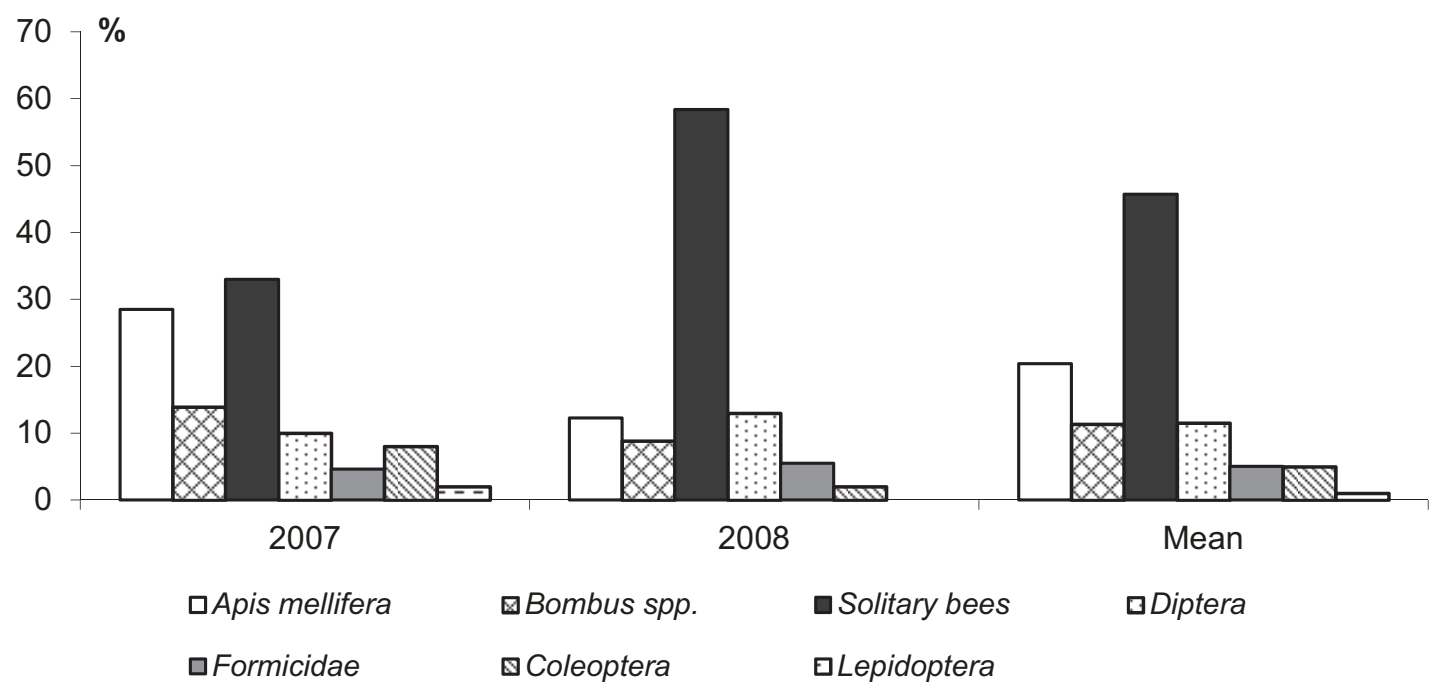

Fig. 5. The relative abundance of insect visitors to the flowers of Campanula bononiensis observed in 2007 and 2008 in SE Poland.

Table 2

The fresh and dry mass of 10 anthers and the mass of pollen produced per 10 anthers, the percentage participation of pollen in anthers and pollen viability of Campanula bononiensis in the years 2007-2009. Values within columns followed by the same letters are not significantly differ between years at $P=0.05$ according to Tukey's HSD test.

\begin{tabular}{|c|c|c|c|c|c|c|c|c|c|}
\hline \multirow{3}{*}{ Year } & \multicolumn{4}{|c|}{ Mass of 10 anthers with pollen (mg) } & \multirow{2}{*}{\multicolumn{3}{|c|}{ Mass of pollen per 10 anthers $(\mathrm{mg})$}} & \multirow{2}{*}{\multicolumn{2}{|c|}{ Viability (\%) }} \\
\hline & \multicolumn{2}{|c|}{ Fresh } & \multicolumn{2}{|c|}{ Dry } & & & & & \\
\hline & Mean & $\pm \mathrm{SD}$ & Mean & $\pm \mathrm{SD}$ & Mean & $\pm \mathrm{SD}$ & $\%$ & Mean & $\pm \mathrm{SD}$ \\
\hline 2007 & $6.4_{\mathrm{a}}$ & 6.0 & $3.0_{\mathrm{a}}$ & 1.1 & $0.8 \mathrm{a}$ & 0.4 & 26.7 & $75.5 \mathrm{a}$ & 6.5 \\
\hline 2008 & $7.9_{\mathrm{b}}$ & 0.9 & $4.3_{\mathrm{b}}$ & 0.7 & $1.5_{\mathrm{b}}$ & 0.5 & 34.8 & $97.0_{\mathrm{b}}$ & 4.5 \\
\hline 2009 & $4.3_{\mathrm{c}}$ & 1.8 & $2.7_{\mathrm{a}}$ & 1.8 & $0.5_{\mathrm{a}}$ & 0.3 & 18.5 & $38.8_{\mathrm{c}}$ & 2.0 \\
\hline Mean & 6.2 & & 3.3 & & 1.6 & & 31.5 & 70.4 & \\
\hline
\end{tabular}

\section{DISCUSSION}

Campanula bononiensis was a component of typical xerothermic phytocoenoses from the Festuco-Brometea class, analogous to that observed in other central European countries [22]. A decrease in the number of individuals and in the abundance of flowering between growing seasons was observed and this was presumably related to the overgrowing processes present in the patch. The encroachment of shrubs (e.g. Prunus spinosa, also noted in the phytocoenoses studied) is considered as the main factor for the decline in many herbaceous plant populations in communities from the Festuco-Brometea class [27, 28]. The decrease in the abundance of flowering, combined with the effect of patch overgrowing, may also be influenced by fluctuations in environmental conditions, e.g. weather factors during the growing period. A highly significant correlation between the abundance of flowering (density of individuals, the number of developed flowers) and meteorological factors was noted for species from the genus Campanula [29].
The flowering period of Campanula bononiensis in SE Poland may last from 6 up to 10 weeks. On average, the flowering begins in late June and may extend till the middle of September. Seasonal shifts are due to weather conditions varying between years. Generally, high temperatures speeded up the blooming process, while prolonged rainfall inhibited flowering. The dependence of flowering on heterogeneous climate conditions is highlighted for many plant species [i.e. $7,25,30]$, including species from the genus Сатрапиla [29]. The majority of flowers open between 10.00 and $16.00 \mathrm{~h}$, similarly to C. rapunculus flowers described by Schlindwein et al. [15].

The proportion of pollen in anthers differed (18.5-34.8 \%) and therefore the mass of pollen produced in anthers varied (0.5-1.5 mg per 10 anthers) between growing seasons. The lowest pollen production was probably attributed to a lack of rainfall, as the decrease in the mass of produced pollen was noted during the year with a rainfall deficit (precipitation approx. $75 \%$ lower compared to the long-term average). The effect of drought on the decline in pollen produc- 
tion has been found by different authors $[8,31]$. The lowest pollen viability (only $38.8 \%$ ) was also recorded in the year with low precipitation. Pollen viability can vary considerably depending on different weather factors (relative humidity, temperature) and water deficit is considered as particularly important for protoplast formation, although the response of plants to stress conditions can differ $[5,7,32,33]$.

The corolla of $C$. bononiensis shows subtle changes in the color during flower development. This could be used by pollinators to help in distinguishing between rewarding and unrewarding flowers and is common among entomophilous taxa [4, 9]. The flowers of $C$. bononiensis are strictly protandrous. This kind of dichogamy is characteristic for the family Campanulaceae [9] and is considered as a mechanism to avoid self-pollination [20]. In the flowers of C. bononiensis, the dehiscence of anthers begins at the bud stage; the process of pollen release is very rapid and when the corolla opens the pollen from all the anthers is presented on the style. A rapid mechanism of pollen presentation is known in a few families, e.g. Orchidaceae and Asteraceae, and is associated with the androecium consisting of a few stamens [5, 30]. This mechanism contrasts with flowers that develop numerous stamens and show a prolongation of pollen presentation by a regular pattern of pollen release [8, 32]. Due to the secondary pollen presentation, the process of pollen exposition extended for approx. 2 days per single flower of $C$. bononiensis. In the case of protandrous species, the prolongation of the male phase is an advantage based on phenology and the availability of ovules increases rapidly during the flowering season $[34,35]$. The secondary pollen presentation in C. bononiensis definitely increases the mating opportunities by the extension of the availability of male gametes for reproduction and allows the transfer of pollen for cross-pollination.

The style presenter of $C$. bononiensis is covered with trichomes, a feature known widely in Campanulaceae [e.g. 4, 9]. Similarly to other Campanula species described [20], the elongation of the style and the unfolding of the three lobes took place after anther dehiscence; thus the stigma could receive substantial quantities of cross-pollen. We also observed that the disappearance of trichomes of the style correlates with the end of pollen presentation and with the unfolding of the stigma lobes, similar to that described by Weryszko-Chmielewska and Bartyś [19]. When the function of the style's trichomes ended, the female phase followed the male phase. It seems that the disappearance of the trichomes additionally restricts the risk of self-pollination. Otherwise, the plant saves energy when a component of the flower that has finished functioning is destroyed [18].
The pollen grain of $C$. bononiensis is medium sized, within a range $(26-50 \mu \mathrm{m})$ defined by $\mathrm{Erdt}$ $\mathrm{m}$ a n [36] and M o o r e et al. [37] as characteristic for Campanula type.

Campanula bononiensis offered both nectar and pollen as the floral reward and the flowers were attractive to a variety of insect visitors, not only Apoidea. Mating and sleeping dipterans as well as ants were observed in the flowers. According to $\mathrm{Szafer}$ and Wojtusiakowa [16], Campanula flowers emit heat radiation. The pollen presenter is presumably involved in the process. Dipterans and ants, known to be temperature sensitive, were observed close to the pollen presenter. Their behavior in the flowers provide evidence for the combined function of the flower (food, shelter), thereby implying a strong impact of $C$. bononiensis on insect biodiversity.

The participation of insect visitors varied between years. The temporal changes in the guild of insect visitors to $C$. bononiensis flowers could be associated with different factors, e.g. the variable density of individuals, the varying abundance of blooming, the variations in the quantity of flower reward offered or the changes in accompanying vegetation. A similar conclusion was made by Gouls on [10] who found that insect foragers preferred to visit abundantly flowering areas that ensure high quantity of resources. Also co-flowering species likely impact the differences in the participation of insect visitors [10, 38]. We observed that the accompanying species varied between years, i.e. Centaurea scabiosa, a taxon regarded as very attractive for the honeybee [30], was present in 2008 but not in 2007. This potentially could affect the lower participation of Apis mellifera on the $C$. bononiensis flowers in 2008, compared with 2007. Additionally, the population size of Apis mellifera undoubtedly varied annually and is related to the activity of local beekeepers. The other possible important factor in the distribution of foragers, e.g. solitary bees (33-58\%), was likely due to the location of nests within the area and to the insect population size which fluctuates between growing seasons. Incredibly intriguing was a very low frequency of butterflies and their absolute absence in one year of the study. Butterflies have been regularly observed on various Campanula species across European countries $[4,15,16,39,40]$. However, according to a report from the European Environment Agency (EEA), grassland butterflies have declined dramatically between 1990 and 2011 [41]. Likewise, this negative trend may explain the lack of butterflies in our biocenosis.

\section{Authors' contributions}

Concept of the study - BD, MW; field work - BD, MW, MS-A; photographs - BD, MW, MB; 
laboratory analysis - $\mathrm{BD}, \mathrm{MB}, \mathrm{AJ}$; statistical analysis $-\mathrm{BD}$; writing the manuscript $-\mathrm{BD}$.

\section{Acknowledgements}

The material from protected species was collected in compliance with Polish law under the permit from the Regional Nature Conservator in Lublin. We gratefully thank Michał Wrzesien for his logistic support during the field study. This research was supported financially by the Ministry of Science and Higher Education of Poland as part of the statutory activities of the Department of Botany, University of Life Sciences in Lublin.

\section{REFERENCES}

1. Schemske DW, Husband BC, Ruckelshaus MH, Goodwille C, Parker IM, Bishop JG. Evaluating approaches to the conservation rare and endangered plants. Ecology. 1994; 75: 584-606. http://dx.doi.org/doi: 10. 2307/1941718

2. Potts SG, Biesmeijer JC, Kremen C, Neumann P, Schweiger O, Kunin WE. Global pollinator declines: trends, impacts and drivers. Trends Ecol. Evol. 2010; 25: 345-353. http://dx.doi.org/10.1016/j.tree. 2010.01.007

3. Essenberg CJ. Scale-dependent shifts in the species composition for flower visitors with changing floral density. Oecologia. 2013; 171: 7196. http://dx.doi.org/10.1007/ s00442-012-2391-z

4. Faegri K, van der Pijl L. The principles of pollination ecology. Pergamon Press. 1979; 244 pp.

5. Pa cin i E. From anther and pollen ripening to pollen presentation. Plant Syst. Evol. 2000; 222: 19-43. http://dx.doi. org/10.1007/BF00984094

6. Denis ow B. Flowering and pollen production of several f. Brassicaceae ornamentals. J. Apic. Sci. 2008; 52(2): 13-21.

7. Denisow B. Pollen production, flowering and insects visits on Euphorbia cyparissias L. and Euphorbia virgultosa Klok. J. Apic. Res. 2009; 48(1): 50-59. http://dx.doi. org/10.3896/IBRA.1.48.1.11

8. Den is ow B. Pollen production of selected ruderal plant species in the Lublin area. Univ. Life Science Press. Lublin. 2011; 351: 86 pp.

9. Proctor M, Yeo P, Lack P. The natural history of pollination. Harper Collins Publishers, London, UK; 1996.

10. Gouls on D. Foraging strategies of insects for gathering nectar and pollen, and implications for plant ecology and evolution. Perspect. Plant Ecol. 1999; 2(2): 185-209. http://dx. doi.org/10.1078/1433-8319-00070

11. Heywood VH. Flowering plants of the world. Croom Helm, London. 1985; 336 pp.

12. Rutkowski L. Klucz do oznaczania roślin naczyniowych Polski niżowej. Wydawnictwo Naukowe PWN, Warszawa; 2011. (in Polish).
13. Denisow B, Wrzesień M. The anthropogenic refuge areas for bee flora in agricultural landscape. Acta Agrobot. 2007; 60(1): 147-157. http://dx.doi.org/10.5586/ aa.2007.018

14. Delaplane KS, Mayer DJ. Crop pollination by bees. CABI Publishing. 2000; 325 pp http://dx.doi.org/ 10.1079/9780851994482.0000

15. Schlindwein C, Wittmann D, Martins CF, Hamm A, Siqueira JA, Schiffler D, Machado IC . Pollination of Campanula rapunculus L. (Campanulaceae): How much pollen flows into pollination and into reproduction of oligolectic pollinators? Plant Syst. Evol. 2005; 250: 147-156. http://dx.doi.org/10.1007/s00606-004-0246-8

16. Szafer W, Wojtusiakowa H. Kwiaty i zwierzęta. Zapylanie i ekologia roślin. PWN, Warszawa; 1969. (in Polish).

17. Bertin RI, Newman CM. Dichogamy in the angiosperms. Bot. Rev. 1993; 59: 112-152. http://dx.doi.org/ 10.1007/BF02856676

18. Erbar C, Leins P. Portioned pollen release and the syndromes of secondary pollen presentation in Campanulales-Asterales complex. Flora. 1995; 190: 323-338.

19. Weryszko-Chmielewska E, Bartyś E. Obfitość pylenia trzech gatunków z rodzaju Campanula oraz morfologia prezentera pyłkowego C. rapunculoides $\mathrm{L}$. Bibl. Fragm. Agron. 1999; 6: 183-188. (in Polish)

20. Nyman Y. Pollination mechanisms in six Cатрапиla species (Campanulaceae). Plant Syst. Evol. 1992; 181: $97-108$.

21. Hanley ME, Franco M, Pichon S, Darvill B, Goulson D. Breeding system, pollinator choice and variation in pollen quality in British herbaceous plants. Funct. Ecol. 2008; 22: 592-598. http://dx.doi.org/10.1111/j.1365-24 35.2008.01415.x

22. Paul W. Xerothermic species of the genus Campanula in Poland - a model for the phylogeographical assessment of reconstruction post-glacial migration rutes. Ann. Univ. Mariae Curie-Skłodowska, Sect. C. 2012; LXVII, 1: 28-36. doi: 10.2478/v10067-012-0010-3

23. Piękoś-Mirkowa H, Mirek Z. Flora Polski. Atlas roślin chronionych. Multico Oficyna Wydawnicza, Warszawa; 2003. (in Polish).

24. Regulation of the Minister of Environment of 9 July 2004 on wild species of plants under protection. Journal of Laws No 168. 2004.

25. Jabłoński B, Szklanowska K. Wpływ niektórych czynników pogody na kwitnienie, nektarowanie, pylenie i oblot przez owady zapylające entomofilnych roślin uprawnych. / The influence of some weather factors on blooming, nectar secretion, pollen presentation and pollinator foraging on entomophilous crop plants. LTN, Lublin. 1997; 53-58. (in Polish).

26. Stanisz A. Przystępny kurs statystyki z zastosowaniem Statistica na przykładach z medycyny. Statystyki podstawowe. Statsoft Polska, Kraków; 2006. (in Polish).

27. Bachmann U, Hensen I, Partzsch M. Is Campanula glomerata threatened by competition of expanding 
grasses? Plant Ecol. 2005; 180: 257-265. http://dx.doi.org/ $10.1007 / \mathrm{s} 11258-005-3788-0$

28. Dostalek J, Frantik T. Dry grassland plant diversity conservation using low-intensity sheep and goat grazing management: case study in Prague (Czech Republic). Biodiver. Conserv. 2008; 17: 1439-1454. http://dx.doi.org/ $10.1007 / \mathrm{s} 10531-008-9352-1$

29. Blionis GJ, Halley J M, Vokou D. Flowering phenology of Campanula on Mt Olympos, Greece. Ecography. 2001; 24(6): 696-706. http://dx.doi.org/10.1034/j.1600-05 87.2001.240608.x

30. De n is ow B. Blooming biology and pollen abundance of some Centaurea sp. J. Apic. Sci. 2006; 50(2): 13-20.

31. Khanduri VP. Variation in anthesis and pollen presentation in plants. American- Euroasian J. Agric. Environ. Sci. 2011; 11: 843-836.

32. Shivanna KR, Linskens HF, Cresti M. Pollen viability and pollen vigor. Theoretical and Applied Genetics. 1991; 81: 38-42. http://dx.doi.org/10.1007/BF00226109

33. Szklanowska K. The pollen flows of crowfoot family (Ranunculaceae L.) from natural plants communities. In: Changes in Fauna of Wild Bees in Europe. Pedagogical University, Bydgoszcz. 1995; 201-214.

34. Robertson AW, Lloyd D. Rates of pollen deposition and removal in Myosotis colensoi. Functional Ecology 1993; 7: 549-559. http://www.jstor.org/stable/2390131.

35. Obes o J R. The costs of reproduction in plants. New Phytol. 2002; 155: 321-348. http://dx.doi.org/10.1046/j.1469-81 37.2002.00477.x

36. Erdtman G. Morfologija pylcy i sistematika rastienij. Izdatelstvo Inostrannoj Literatury, Moskva: 1956. (in Russian).

37. Moore PD, Webb JA, Collins on ME. Pollen analysis. Second Edition. Blackwell Sci. Publi., Oxford; 1991.

38. Fussel M, Corbet SA. Flower usage by bumble-bees: a basis for forage plant management. J. Appl. Ecol. 1992; 29: 451-465. http://dx.doi.org/10.2307/2404513

39. Knuth P. Handbuch der Blütenbiologie, II Band, 2. Teil: Ranunculaceae bis Compostitae. Leipzig, Verlagvon Wilhelm Engelman; 1898. https://archive.org/details/handbuchderblte01mlgoog
40. Blionis GJ, Vokou D. Pollination ecology of Campanula species on Mt Olympos, Greece. Ecography. 2001; 24(3): 287-297. http://dx.doi.org/10.1111/j.1600-0587.2001. tb00201.x

41. B r u y ninckx H. The European Grassland Butterfly Indicator: 1990-2011. European Environment Agency. Technical report No 11/2013. http://www.eea.europa.eu/highlights/populations-of grassland-butterflies-decline

\section{Kwitnienie, cechy pyłku oraz owady wizytujące kwiaty chronionego gatunku Campanula bononiensis (Campanulaceae)}

\section{Streszczenie}

W pracy przedstawiono wyniki badań dotyczące aspektów kwitnienia, cech ilościowych i jakościowych pyłku Campanula bononiensis L. (Campanulaceae), gatunku objętego w Polsce ustawową ochroną. Obserwacje prowadzono latach 2007-2009, w naturalnej fitocenozie z klasy Festuco-Brometea zlokalizowanej w Lublinie. Zanotowano znaczny, ok. 87\% spadek zagęszczenia populacji. Poza procesami sukcesyjnymi, prowadzącymi do zarastania murawy, zanikanie populacji $C$. bononiensis może być związane z wewnętrznymi czynnikami biologicznymi, np. ilością i jakością wytwarzanego pyłku. W latach badań zanotowano znaczne wahania w ilości produkowanego pyłku (18.5\%-34.8\% suchej masy pylników, tj. $0.5-1.5 \mathrm{mg}$ z 10 pylników) oraz istotne zróżnicowanie jego żywotności (38.8-97.0\%).

Najczęściej obserwowanymi owadami wizytującymi kwiaty były owady pszczołowate (Apoidea). Pszczoły samotnice stanowiły $45.7 \%$ ogólnej liczebności owadów, $20.4 \%$ wyniósł udział pszczoły miodnej, a $11.4 \%$ stanowiły różne gatunki z rodzaju Bombus. Obserwowano również muchówki, chrząszcze ryjkowce, motyle oraz mrówki, co świadczy o dużym wpływie $C$. bononiensis na bioróżnorodność owadów w obrębie muraw ciepłolubnych.

Handling Editor: Elżbieta Pogroszewska

This is an Open Access digital version of the article distributed under the terms of the Creative Commons Attribution 3.0 License (creativecommons.org/licenses/by/3.0/), which permits redistribution, commercial and non-commercial, provided that the article is properly cited.

(C)The Author(s) 2014 Published by Polish Botanical Society 